\title{
Milk Fatty Acid Unsaturation: Genetic Parameters and Effects of Stearoyl-CoA Desaturase (SCD1) and Acyl CoA: Diacylglycerol Acyltransferase 1 (DGAT1)
}

\author{
A. Schennink, ${ }^{\star 1,2}$ J. M. L. Heck, $\dagger^{1}$ H. Bovenhuis, ${ }^{*}$ M. H. P. W. Visker, ${ }^{*}$ H. J. F. van Valenberg, $\dagger$ \\ and J. A. M. van Arendonk* \\ *Animal Breeding and Genomics Centre, Wageningen University, PO Box 338, 6700 AH Wageningen, the Netherlands \\ †Dairy Science and Technology Group, Wageningen University, PO Box 8129, 6700 EV Wageningen, the Netherlands
}

\begin{abstract}
With regard to human health aspects of milk fat, increasing the amount of unsaturated fatty acids in milk is an important selection objective. The cow's diet has an influence on the degree of unsaturation, but literature suggests that genetics also plays a role. To estimate genetic variation in milk fatty acid unsaturation indices, milk fatty acid composition of 1,933 Dutch Holstein Friesian heifers was measured and unsaturation indices were calculated. An unsaturation index represents the concentration of the unsaturated product proportional to the sum of the unsaturated product and the saturated substrate. Intraherd heritabilities were moderate, ranging from $0.23 \pm 0.07$ for conjugated linoleic acid (CLA) index to $0.46 \pm 0.09$ for $\mathrm{C} 16$ index. We genotyped the cows for the SCD1 A293V and DGAT1 K232A polymorphisms, which are known to alter milk fatty acid composition. Both genes explain part of the genetic variation in unsaturation indices. The SCD1 V allele is associated with lower C10, C12, and $\mathrm{C} 14$ indices, and with higher C16, C18, and CLA indices in comparison to the SCD1 A allele, with no differences in total unsaturation index. In comparison to the DGAT1 $\mathrm{K}$ allele, the DGAT1 A allele is associated with lower $\mathrm{C} 10, \mathrm{C} 12, \mathrm{C} 14$, and $\mathrm{C} 16$ indices and with higher C18, CLA, and total indices. We conclude that selective breeding can contribute to higher unsaturation indices, and that selective breeding can capitalize on genotypic information of both the SCD1 A293V and the DGAT1 K232A polymorphism.
\end{abstract}

Key words: milk fatty acid composition, SCD1, DGAT1, dairy cow

Received November 3, 2007.

Accepted January 8, 2008.

${ }^{1}$ A. Schennink and J. M. L. Heck contributed equally to this work.

${ }^{2}$ Corresponding author: anke.schennink@wur.nl

\section{INTRODUCTION}

Recent studies show that bovine milk fatty acid composition is determined to a large extent by genetics, indicating that selective breeding can be an effective means to alter the composition of milk fat (Schennink et al., 2007; Soyeurt et al., 2007). Milk fat is characterized by a high amount of saturated fatty acids, especially myristic acid (C14:0) and palmitic acid (C16:0), and by a low amount of (poly)unsaturated fatty acids. With regard to human health aspects, increasing the amount of unsaturated fatty acids in milk is an important selection objective.

The cow's diet plays a role in determining the degree of unsaturation of milk fat (Baumgard et al., 2000; Perfield et al., 2006, 2007). Dietary fatty acids are hydrogenated in the rumen by bacteria and transported via the blood. In the mammary gland, fatty acids originating from the blood or from de novo fatty acid synthesis can be desaturated. Eventually, the fatty acids that are secreted into the milk determine the degree of unsaturation of milk fat. This degree of unsaturation is often addressed by a so-called index: the concentration of the unsaturated product proportional to the sum of the unsaturated product and the saturated substrate.

Studies demonstrating a significant variation in unsaturation among breeds and cows on the same diet suggest that also genetics plays a role (Beaulieu and Palmquist, 1995; DePeters et al., 1995; Lawless et al., 1999; Sol Morales et al., 2000; Drackley et al., 2001; Kelsey et al., 2003; Lock and Garnsworthy, 2002, 2003). For example, Kelsey et al. (2003) found that the milk-fat content of C18:2 cis-9, trans-11 (conjugated linoleic acid, CLA) and the CLA index varied largely among individual cows on the same diet, namely over 3 -fold. Lock and Garnsworthy (2002 and 2003) reported that the C14:1/C14:0 index differed significantly between cows. However, genetic parameters for milk fatty acid unsaturation indices are scarce in literature (Royal and Garnsworthy, 2005). 
Animals are capable of desaturating saturated fatty acids to $\Delta^{9}$ unsaturated fatty acids by the stearoylCoA desaturase (SCD) enzyme, which catalyzes the insertion of a double bond between carbon atoms 9 and 10 of a fatty acid (Pereira et al., 2003). Two SCD isoforms have been identified in cattle, SCD1 and $S C D 5$; SCD1 is located on chromosome 26 and expressed in a variety of tissues among which are adipose and mammary tissue, and SCD5 is located on chromosome 6 and expressed primarily in the brain (Chung et al., 2000; Lengi and Corl, 2007). A nonsynonymous SNP in exon 5 of $S C D 1$, causing the substitution of valine with alanine (A293V), has been associated with carcass fatty acid composition in Japanese Black cattle (Taniguchi et al., 2004) and with milk fatty acid composition in Italian Holstein, Piedmontese, and Valdostana cattle (Mele et al., 2007; Moioli et al., 2007). The SCD1 A allele was associated with a higher monounsaturated fatty acid content.

Another candidate gene that may affect unsaturation is acyl CoA:diacylglycerol acyltransferase 1 (DGAT1), which is located on chromosome 14 (Grisart et al., 2002). The DGAT1 enzyme plays a key role in triacylglycerol synthesis; it catalyzes the esterification of a fatty acyl-CoA to the $s n-3$ position of a diacylglycerol. A lysine to alanine polymorphism in DGAT1 (K232A) explains $50 \%$ of the genetic variation in milkfat percentage and also has a strong effect on milk fatty acid composition. The DGAT1 $\mathrm{K}$ allele was associated with a larger fraction of $\mathrm{C} 16: 0$; and smaller fractions of C14:0, unsaturated C18, and CLA (Schennink et al., 2007).

Our study aims to estimate genetic variation for milk fatty acid unsaturation indices for specific fatty acids and their phenotypic and genetic correlations. Furthermore, we study the effects of polymorphisms in 2 candidate genes, namely SCD1 A293V and DGAT1 $\mathrm{K} 232 \mathrm{~A}$, on milk fatty acid unsaturation indices.

\section{MATERIALS AND METHODS}

\section{Animals}

This study is part of the Dutch Milk Genomics Initiative, which focuses on the genetic background of detailed milk composition. As part of this study, morning milk samples and blood samples were collected from 1,933 first-lactation cows on 398 commercial herds in the Netherlands. A 0.5-L milk sample was collected from each cow at 1 morning milking between February and March 2005. At least 3 cows per herd were sampled, and cows were milked twice a day. Cows descended from 1 of 50 young bulls (845 cows), from 1 of 5 proven bulls (897 cows), or from other proven bulls (191 cows). The NRS (Arnhem, the Netherlands) pro- vided pedigrees of the cows and the milk yield records. Total pedigree size was 26,300 records. Each cow was over $87.5 \%$ Holstein-Friesian and was in lactation between $\mathrm{d} 63$ and 282.

\section{Phenotypes}

Fat and protein percentages were measured by infrared spectroscopy, using a MilkoScan FT6000 (Foss Electric, Hillerød, Denmark) at the Milk Control Station (Zutphen, the Netherlands). Fat and protein yields were calculated by multiplying fat or protein percentage by the morning milk yield. Milk yield $(\mathrm{kg})$ data were missing for 145 cows. Milk fatty acid composition was measured by gas chromatography at the COKZ laboratory (Netherlands Controlling Authority for Milk and Milk Products, Leusden, the Netherlands) as described by Schennink et al. (2007). With this method, the C18:1 cis-9 peak was probably slightly overestimated due to coelution (Jensen, 2002). The cis double bond of $\mathrm{C} 10: 1$ and $\mathrm{C} 12: 1$ could not be ascertained at the carbon-9 position. The fatty acids were expressed as weight-proportion of total fat weight. Fatty acid unsaturation indices were calculated by expressing each product as a proportion of the product plus substrate, multiplied by 100 (Kelsey et al., 2003):

$$
\begin{aligned}
& \frac{\text { unsaturated }}{\text { unsaturated }+ \text { saturated }} \times 100, \\
& \text { e.g., } \frac{C 14: 1 \text { cis- } 9}{C 14: 1 \text { cis }-9+C 14: 0} \times 100 \text {. }
\end{aligned}
$$

We calculated indices for the following product and substrate pairs: C10:1 and C10:0 (C10 index), C12:1 and $\mathrm{C} 12: 0$ (C12 index), C14:1 cis-9 and C14:0 (C14 index), C16:1 cis-9 and C16:0 (C16 index), C18:1 cis9 and C18:0 (C18 index), C18:2 cis-9, trans-11 (CLA), and C18:1 trans-11 (CLA index).

\section{Genotypes}

Blood samples for DNA isolation were collected between April and June 2005. Genotypes for the SCD1 A293V polymorphism were assayed by the SNaPshot single base primer extension method (Applied Biosystems, Foster City, CA). The primer designs were based on the GenBank sequence (AY241932): forward PCR primer, 5'-TCATTTAACCCCTCATTACCTCA-3'; reverse PCR primer, $5^{\prime}$-TGTAAAATACTAGGCTTTCT GG-3'; genotyping primer, 5'-TGGTTTCCCTGGGAG CTG-3'. To amplify the SCD1 fragment, $12-\mu \mathrm{L}$ PCR reactions were set up containing $20 \mathrm{ng}$ of genomic DNA, $0.2 \mu M$ of each primer, and $2 \times$ AccuPrime Supermix II (Invitrogen, Carlsbad, CA). The PCR cycling 
conditions were $94^{\circ} \mathrm{C}$ for $5 \mathrm{~min}, 36$ cycles of $94^{\circ} \mathrm{C}$ for $30 \mathrm{~s}, 55^{\circ} \mathrm{C}$ for $45 \mathrm{~s}, 68^{\circ} \mathrm{C}$ for $90 \mathrm{~s}$, followed by an extension cycle of $68^{\circ} \mathrm{C}$ for $10 \mathrm{~min}$. The PCR products were purified by incubation with shrimp alkaline phosphatase (USB, Cleveland, OH) and Exo I (USB) at $37^{\circ} \mathrm{C}$ for $1 \mathrm{~h}$ and $72^{\circ} \mathrm{C}$ for $15 \mathrm{~min}$. Extension reactions, using $3 \mu \mathrm{L}$ of purified PCR product and 5 pmol of genotyping primer and SNaPshot multiplex Ready reaction mix (Applied Biosystems), were performed using 40 cycles of $96^{\circ} \mathrm{C}$ for $10 \mathrm{~s}, 50^{\circ} \mathrm{C}$ for $5 \mathrm{~s}$, and $60^{\circ} \mathrm{C}$ for $30 \mathrm{~s}$. The extension products were incubated with shrimp alkaline phosphatase at $37^{\circ} \mathrm{C}$ for $1 \mathrm{~h}$ and $72^{\circ} \mathrm{C}$ for $15 \mathrm{~min}$. Two microliters of extension product were added to 8 $\mu \mathrm{L}$ of Hi-Di formamide and electrophoresed on an ABI 3730 DNA analyzer. Results were analyzed using the GeneMapper Software v4.0 (Applied Biosystems). In total, 1,725 animals were genotyped for the SCD1 A293V polymorphism. Genotypes were missing for 208 animals because either no DNA sample was available $(\mathrm{n}=141)$ or the sample could not be genotyped unambiguously ( $\mathrm{n}=67$ ).

Genotyping of the DGAT1 K232A dinucleotide polymorphism was performed as described by Schennink et al. (2007). In total, 1,779 animals were genotyped for the DGAT1 polymorphism. Genotypes were missing for 154 animals because either no DNA sample was available $(n=141)$ or the sample could not be genotyped unambiguously $(\mathrm{n}=13)$.

\section{Statistical Analysis}

Analyses were performed first using SAS 9.1 (2002) procedures to determine significance of fixed effects. The model included DIM (days between calving and date of sample), age at first calving, season of calving, and an effect of the differences in genetic level between proven bull daughters and young bull daughters. Variance components and genetic parameters were estimated using an Animal model in ASReml (Gilmour et al., 2002):

$$
\begin{gathered}
\mathrm{y}_{\mathrm{ijklmn}}=\mu+\mathrm{b}_{1} \times \operatorname{dim}_{\mathrm{i}}+\mathrm{b}_{2} \times \mathrm{e}^{-0.05 \times \operatorname{dim}}+\mathrm{b}_{3} \times \mathrm{afc}_{\mathrm{j}}+\mathrm{b}_{4} \\
\times \operatorname{afc}_{\mathrm{j}}^{2}+\operatorname{season}_{\mathrm{k}}+\operatorname{scode}_{1}+\operatorname{herd}_{\mathrm{m}}+\mathrm{a}_{\mathrm{n}}+\mathrm{e}_{\mathrm{ijklmn}},
\end{gathered}
$$

where y was the dependent variable, $\mu$ was the general mean, dim was the covariate describing the effect of DIM modeled with a Wilmink curve (Wilmink, 1987), afc was the covariate describing the effect of age at first calving, season was the fixed effect of the class of calving season (June-August 2004, September-November 2004, or December 2004-February 2005), scode was the fixed effect of the differences in genetic level between proven bull daughters and young bull daughters, herd was the random effect of groups of animals sampled in the same herd, $a_{n}$ was the random additive genetic effect of animal $n$, and e was the random residual effect. Effects of the polymorphisms were estimated using the same model, but extended with effect g: the fixed effect of the SCD1 genotype (AA, $\mathrm{AV}$, or VV) or the DGAT1 genotype (KK, KA, or AA). Ungenotyped individuals were included as a separate group and appeared to be randomly distributed across other effects in the model.

The variance-covariance structure of the additive genetic effects was $\operatorname{Var}(\mathrm{a})=\mathrm{A} \sigma_{\mathrm{a}}^{2}$, where $\mathrm{A}$ was a matrix of additive genetic relationships between individuals and $\sigma_{\mathrm{a}}{ }^{2}$ was the additive genetic variance. Heritabilities were estimated using univariate analyses. Heritability was defined as

$$
h_{I H}^{2}=\frac{\sigma_{a}^{2}}{\sigma_{a}^{2}+\sigma_{e}^{2}},
$$

where $\sigma_{\mathrm{a}}^{2}$ was the additive genetic variation, and $\sigma_{\mathrm{e}}^{2}$ was the residual variation. Heringstad et al. (2006) referred to this heritability as the intraherd heritability. The intraherd heritability is the parameter that is required to predict selection responses of alternative breeding strategies. The proportion of variance due to herd $\left(h_{\text {herd }}\right)$ was defined as

$$
h_{\text {herd }}=\frac{\sigma_{\text {herd }}^{2}}{\sigma_{\text {herd }}^{2}+\sigma_{a}^{2}+\sigma_{e}^{2}},
$$

where $\sigma_{\text {herd }}^{2}$ was the herd variance. The proportion of additive genetic variance explained by the polymorphism was defined as

$$
r_{\text {genetic }}^{2}=\frac{\sigma_{\text {polymorphism }}^{2}}{\sigma_{a}^{2}},
$$

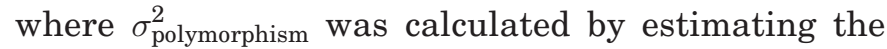
variance of the polymorphism based on the estimated genotype effects and the genotype frequencies. Corrected means for the reference group in Tables 3, 4, and 5 were estimated by the PREDICT function in ASReml. Genetic correlations were estimated using bivariate analyses. Estimates of skewness and kurtosis for the fatty acid indices are in the same range as the estimates for milk production traits.

\section{RESULTS AND DISCUSSION}

\section{Means and Coefficients of Variation}

Fatty acid unsaturation indices were calculated from milk fatty acid profiles of 1,933 Dutch Holstein 
Table 1. Mean, coefficient of variation (CV), $5 \%$, and $95 \%$ quantiles for fatty acid unsaturation indices, measured on 1 morning milk sample of 1,933 first-lactation Dutch Holstein-Friesian cows

\begin{tabular}{|c|c|c|c|c|}
\hline Trait & Mean & $\begin{array}{l}\text { CV } \\
(\%)\end{array}$ & $\begin{array}{c}5 \% \\
\text { quantile }\end{array}$ & $\begin{array}{c}95 \% \\
\text { quantile }\end{array}$ \\
\hline C10 index ${ }^{1}$ & 10.9 & 17 & 6.6 & 14.9 \\
\hline C12 index ${ }^{1}$ & 2.7 & 20 & 1.6 & 3.9 \\
\hline C14 index ${ }^{1}$ & 10.5 & 17 & 7.0 & 14.6 \\
\hline C16 index ${ }^{1}$ & 4.2 & 19 & 2.9 & 6.3 \\
\hline C18 index ${ }^{1}$ & 67.6 & 6 & 59.5 & 75.3 \\
\hline CLA index ${ }^{2}$ & 33.7 & 12 & 25.4 & 42.8 \\
\hline Total index ${ }^{3}$ & 26.4 & 10 & 21.5 & 33.1 \\
\hline
\end{tabular}

${ }^{1}$ Indices are calculated according to the following example: C14 index $=\mathrm{C} 14: 1 \mathrm{cis}-9 /(\mathrm{C} 14: 1 \mathrm{cis}-9+\mathrm{C} 14: 0) \times 100$.

${ }^{2}$ CLA index = CLA cis-9, trans-11/(CLA cis-9, trans $-11+\mathrm{C} 18: 1$ trans-11) $\times 100$.

${ }^{3}$ Total index $=(\mathrm{C} 10: 1+\mathrm{C} 12: 1+\mathrm{C} 14: 1$ cis $-9+\mathrm{C} 16: 1$ cis $-9+\mathrm{C} 18: 1$ cis $-9+$ CLA cis -9, trans -11$) /(\mathrm{C} 10: 1+\mathrm{C} 12: 1+\mathrm{C} 14: 1$ cis $-9+\mathrm{C} 16: 1$ cis $9+\mathrm{C} 18: 1$ cis $-9+\mathrm{CLA}$ cis -9, trans $-11+\mathrm{C} 10: 0+\mathrm{C} 12: 0+\mathrm{C} 14: 0+\mathrm{C} 16: 0$ $+\mathrm{C} 18: 0+\mathrm{C} 18: 1$ trans -11$) \times 100$.

Friesian heifers (Table 1). Unsaturation indices of the short and medium-chain fatty acids C10, C12, C14, and $\mathrm{C} 16$ were between 2.7 and 10.9. Indices of the long-chain fatty acids C18 and CLA were higher, 67.6 and 33.7, respectively. These values are in line with those reported for dairy cattle in other studies (Royal and Garnsworthy, 2005; Perfield et al., 2006, 2007; Mele et al., 2007). Almost all C10, C12, C14, and approximately $50 \%$ of $\mathrm{C} 16$ fatty acids are synthesized in the mammary gland, whereas the longer-chain fatty acids as well as a proportion of the unsaturated longchain fatty acids are derived from the blood. The dual origin of the long-chain fatty acid unsaturation may play a role in the contrast between short/medium and long-chain fatty acid unsaturation indices. An alternative explanation for this contrast may be that longchain fatty acids are unsaturated to a larger extent. The coefficient of variation was lowest for $\mathrm{C} 18$ index (6\%) and highest for $\mathrm{C} 12$ and C16 indices (about 20\%).

\section{Heritabilities and Herd Effects}

Intraherd heritabilities range from 0.23 for CLA index to 0.46 for $\mathrm{C} 16$ index and demonstrate a significant genetic effect on the variation in fatty acid unsaturation indices (Table 2). The heritability for total index was 0.30 . Repeatabilities for $\mathrm{C} 14, \mathrm{C} 16$, and $\mathrm{C} 18$ indices, which are considered to be the upper limit of heritabilities, were estimated between 40 and $45 \%$ by Soyeurt et al. (2006), suggesting moderate heritabilities as well. Only Royal and Garnsworthy (2005) reported heritabilities for fatty acid unsaturation indices, based on 1,520 Holstein-Friesian cows, and reported similar values for C14 (0.30), C18 (0.19), and CLA (0.29) indices, but much lower values for $\mathrm{C} 16$ (0.01) and total
Table 2. Intraherd heritability $\left(\mathrm{h}_{\mathrm{IH}}^{2}\right)$, herd effect $\left(\mathrm{h}_{\text {herd }}\right)$, additive genetic variance estimate $\left(\sigma_{\mathrm{a}}^{2}\right)$, and ratio between additive genetic variance and herd variance $\left(\sigma_{\mathrm{a}}^{2} / \sigma_{\text {herd }}^{2}\right)$ for fatty acid unsaturation indices, measured on 1 morning milk sample of 1,933 first-lactation Dutch Holstein-Friesian cows

\begin{tabular}{lcccc}
\hline Trait & $\mathrm{h}_{\mathrm{IH}}^{2} \pm \mathrm{SE}$ & $\mathrm{h}_{\text {herd }} \pm \mathrm{SE}$ & $\sigma_{\mathrm{a}}^{2}$ & $\sigma_{\mathrm{a}}^{2} / \sigma_{\text {herd }}^{2}$ \\
\hline C10 index & $0.37 \pm 0.09$ & $0.06 \pm 0.02$ & 1.23 & 5.5 \\
C12 index & $0.37 \pm 0.09$ & $0.06 \pm 0.02$ & 0.09 & 5.6 \\
C14 index & $0.45 \pm 0.09$ & $0.06 \pm 0.02$ & 1.35 & 6.6 \\
C16 index & $0.46 \pm 0.09$ & $0.07 \pm 0.02$ & 0.30 & 6.2 \\
C18 index & $0.33 \pm 0.08$ & $0.06 \pm 0.02$ & 4.36 & 5.1 \\
CLA index & $0.23 \pm 0.07$ & $0.09 \pm 0.02$ & 3.49 & 2.5 \\
Total index & $0.30 \pm 0.09$ & $0.26 \pm 0.02$ & 1.58 & 0.8 \\
\hline
\end{tabular}

(0.02) indices. The proportion of total variance explained by herd was small, ranging from 0.06 to 0.09 of total variance in individual unsaturation indices. For total unsaturation index the herd effect was larger (0.26). The ratio of genetic variance to herd variance showed that for all indices the genetic variance was much larger than the herd variance, except for total index, for which the herd variance was slightly larger than the genetic variance. The total unsaturation index, in fact, mainly represents the ratio of C18:1 cis9 to C16:0 because these fatty acids are the largest unsaturated and saturated fatty acid fractions in milk. The proportion of variance explained by herd was 0.28 for C18:1 cis-9 fraction and 0.29 for C16:0 fraction in milk, which explains the relative large herd variance of the total unsaturation index (Stoop et al., 2008). The moderate to high heritabilities for unsaturation indices in combination with the moderate to high coefficients of variation indicate that the unsaturation indexes can be changed by means of selection.

\section{Effects of the SCD1 A293V Polymorphism}

To study the effect of the SCD1 A293V polymorphism, 1,725 cows were genotyped. The frequency of 293A was 0.73 , and the genotypes were in HardyWeinberg equilibrium. A higher frequency of the A allele is also reported for Italian Holsteins (0.57), Valdostana (0.65), Jerseys (0.94), and Japanese Black cattle (0.59; Taniguchi et al., 2004; Mele et al., 2007; Moioli et al., 2007). The SCD1 genotype did not significantly affect fat or protein percentage, nor fat, protein, or milk yield (results not shown). Effects of the SCD1 genotype on milk fatty acid composition are in Table 3. In comparison to the A allele, the $\mathrm{V}$ allele was associated with a higher proportion of C10:0, C12:0, C14:0, C16:1, and CLA, and with a lower proportion of C10:1, C12:1, C14:1, C18:0, and C18:1 trans-11. Moioli et al. (2007), who studied 27 Piedmontese and 27 Valdostana cows, found similar results, but no signifi- 
Table 3. Effect of the SCD1 A293V polymorphism on milk fatty acid composition ( $\mathrm{g} / 100 \mathrm{~g}$ of total fatty acids)

\begin{tabular}{lccrrr}
\hline Trait & $\begin{array}{c}\text { Predicted mean } \\
\text { of AA group }\end{array}$ & $\begin{array}{c}\mathrm{AA} \\
(\mathrm{n}=919)\end{array}$ & $\mathrm{VA}^{1}(\mathrm{n}=689)$ & $\mathrm{VV}^{2}(\mathrm{n}=117)$ & $P$-value \\
\hline $\mathrm{C} 10: 0$ & 2.95 & 0 & $0.10 \pm 0.02$ & $0.16 \pm 0.04$ & $<0.001$ \\
$\mathrm{C} 10: 1$ & 0.38 & 0 & $-0.03 \pm 0.00$ & $-0.06 \pm 0.01$ & $<0.001$ \\
$\mathrm{C} 12: 0$ & 4.09 & 0 & $0.09 \pm 0.03$ & $0.15 \pm 0.06$ & 0.003 \\
$\mathrm{C} 12: 1$ & 0.12 & 0 & $-0.01 \pm 0.00$ & $-0.02 \pm 0.00$ & $<0.001$ \\
$\mathrm{C} 14: 0$ & 11.38 & 0 & $0.22 \pm 0.04$ & $0.42 \pm 0.09$ & $<0.001$ \\
$\mathrm{C} 14: 1$ cis-9 & 1.46 & 0 & $-0.17 \pm 0.01$ & $-0.33 \pm 0.02$ & $<0.001$ \\
$\mathrm{C} 16: 0$ & 32.67 & 0 & $-0.12 \pm 0.13$ & $-0.25 \pm 0.25$ & 0.58 \\
$\mathrm{C} 16: 1$ cis-9 & 1.38 & 0 & $0.17 \pm 0.02$ & $0.34 \pm 0.03$ & $<0.001$ \\
C18:0 0 & 8.83 & 0 & $-0.30 \pm 0.07$ & $-0.43 \pm 0.13$ & $<0.001$ \\
C18: 1 cis-9 & 18.28 & 0 & $0.08 \pm 0.09$ & $0.17 \pm 0.18$ & 0.55 \\
C18: 1 trans-11 & 0.77 & 0 & $-0.02 \pm 0.01$ & $-0.03 \pm 0.02$ & 0.01 \\
CLA cis-9, trans-11 & 0.38 & 0 & $0.01 \pm 0.00$ & $0.02 \pm 0.01$ & 0.003 \\
\hline
\end{tabular}

${ }^{1}$ Contrast of VA-AA genotypes.

${ }^{2}$ Contrast of VV-AA genotypes.

${ }^{3}$ Statistical significance of the SCD1 A293V polymorphism.

cant effects on C10:0 and C12:0. Mele et al. (2007), who studied 297 Italian Holstein Friesian cows, only found significant effects on C14:1 and on total monounsaturated fatty acids, similar to ours, and on C18:1 cis-9, on which we found no significant effect.

The SCD1 A293V polymorphism had significant effects on the unsaturation indices for all individual fatty acids, but not on the total unsaturation index (Table 4). The $\mathrm{V}$ allele was associated with lower indices of $\mathrm{C} 10, \mathrm{C} 12$, and $\mathrm{C} 14$, and higher indices of $\mathrm{C} 16$, $\mathrm{C} 18$, and CLA. The negative effect of the $\mathrm{V}$ allele on $\mathrm{C} 10$ and $\mathrm{C} 14$ index is in agreement with Moioli et al. (2007); however, they reported no significant effects on the other indices, which could be due to their limited sample size. The negative effect on $\mathrm{C} 14$ index was also found by Mele et al. (2007), but they didn't find a significant effect on other indices.

The finding that the SCD1 polymorphism has highly significant effects on individual indices, but not on the total index, suggests that the activity of the enzyme is not affected. An altered substrate specificity, how- ever, is supported by the differential effects on the individual fatty acid indices. Substrate specificity of SCD enzymes has been demonstrated for SCD isoforms in knockout studies in mice (Miyazaki and Ntambi, 2003). In vitro studies in rat liver microsomal preparations have shown that acyl-CoA derivatives with 12 to 19 carbon atoms were required for activity of the SCD1 enzyme and that the enzyme has substrate specificity with preference for longer-chain fatty acids (Enoch et al., 1976). Based on Enoch et al. (1976), it would be unlikely that $\mathrm{C} 10: 1$ is desaturated from C10:0, which is, however, suggested by our finding that the C10 index is affected by the SCD1 A293V polymorphism. The enzyme function of SCD1 may be affected by the polymorphism because it causes a valine to alanine substitution on position 293 , which is located in the third histidine-rich region of the enzyme. These histidine-rich regions are important for catalytic activity (Shanklin et al., 1994).

The SCD1 A293V polymorphism contributed considerably to the genetic variance (Table 4): it explained

Table 4. Effect of the SCD1 A293V polymorphism on milk fatty acid unsaturation indices

\begin{tabular}{lcccccc}
\hline Trait & $\begin{array}{c}\text { Predicted mean } \\
\text { of AA group }\end{array}$ & $\mathrm{AA}(\mathrm{n}=919)$ & $\mathrm{VA}^{1}(\mathrm{n}=689)$ & $\mathrm{VV}^{2}(\mathrm{n}=117)$ & $P$-value & $\mathrm{r}_{\text {genetic }}^{2}(\%)$ \\
\hline C10 index & 11.68 & 0 & $-1.18 \pm 0.09$ & $-2.16 \pm 0.17$ & $<0.001$ & 41 \\
C12 index & 2.92 & 0 & $-0.29 \pm 0.02$ & $-0.56 \pm 0.05$ & $<0.001$ & 34 \\
C14 index & 11.42 & 0 & $-1.34 \pm 0.08$ & $-2.61 \pm 0.16$ & $<0.001$ & 52 \\
C16 index & 4.05 & 0 & $0.48 \pm 0.04$ & $0.98 \pm 0.08$ & $<0.001$ & 31 \\
C18 index & 67.57 & 0 & $0.87 \pm 0.19$ & $1.43 \pm 0.37$ & $<0.001$ & 6 \\
CLA index & 33.56 & 0 & $1.32 \pm 0.20$ & $2.39 \pm 0.40$ & $<0.001$ & 18 \\
Total index & 26.63 & 0 & $0.05 \pm 0.13$ & $0.10 \pm 0.25$ & 0.85 & $<1$ \\
\hline & \\
& \\
&
\end{tabular}


Table 5. Effect of the DGAT1 K232A polymorphism on milk fatty acid unsaturation indices

\begin{tabular}{lcccccc}
\hline Trait & $\begin{array}{c}\text { Predicted mean } \\
\text { of KK group }\end{array}$ & $\mathrm{KK}(\mathrm{n}=293)$ & $\mathrm{KA}^{1}(\mathrm{n}=837)$ & $\mathrm{AA}^{2}(\mathrm{n}=649)$ & $P$-value & $\mathrm{r}_{\text {genetic }}{ }^{4}(\%)$ \\
\hline C10 index & 11.54 & 0 & $-0.29 \pm 0.12$ & $-0.54 \pm 0.13$ & $<0.001$ & 3 \\
C12 index & 2.92 & 0 & $-0.09 \pm 0.03$ & $-0.20 \pm 0.04$ & $<0.001$ & 5 \\
C14 index & 11.47 & 0 & $-0.47 \pm 0.11$ & $-0.97 \pm 0.12$ & $<0.001$ & 9 \\
C16 index & 4.57 & 0 & $-0.25 \pm 0.05$ & $-0.56 \pm 0.06$ & $<0.001$ & 14 \\
C18 index & 66.46 & 0 & $1.23 \pm 0.24$ & $2.31 \pm 0.26$ & $<0.001$ & 15 \\
CLA index & 32.87 & 0 & $1.15 \pm 0.27$ & $1.90 \pm 0.29$ & $<0.001$ & 12 \\
Total index & 25.67 & 0 & $0.62 \pm 0.16$ & $1.80 \pm 0.17$ & $<0.001$ & 29 \\
\hline & \\
& \\
&
\end{tabular}

31 to $52 \%$ of the genetic variance for $\mathrm{C} 10, \mathrm{C} 12, \mathrm{C} 14$, and $\mathrm{C} 16$ indices, but only $18 \%$ for CLA and $6 \%$ for C18 index (Mosley and McGuire, 2007).

\section{Effects of the DGAT1 K232A Polymorphism}

A total of 1,779 cows was genotyped for the DGAT1 K232A polymorphism. The frequency of $232 \mathrm{~K}$ was 0.40 , and the genotypes were in Hardy-Weinberg equilibrium. The DGAT1 A allele was associated with lower indices of $\mathrm{C} 10, \mathrm{C} 12, \mathrm{C} 14$, and $\mathrm{C} 16$, and with higher indices of $\mathrm{C} 18$ and CLA (Table 5). The A allele was also associated with a higher total unsaturation index. The majority of fatty acids in milk is present in the form of triacylglycerols. DGAT1 catalyzes the last step in triacylglycerol synthesis: the esterification of a fatty acyl-CoA to the $s n-3$ position of a diacylglycerol. The DGAT1 K232A polymorphism was reported to have an effect on, among others, C14:0, C16:0, and unsaturated C18 fatty acids in milk. Given these effects of the polymorphism on milk fatty acid composition, an effect on milk fatty acid unsaturation indices was conceivable. The effects on composition and unsaturation may be explained by different causes: a higher activity of DGAT1 and an alteration of specificity of DGAT1 (Schennink et al., 2007).

\section{Joint Effects of the SCD1 and DGAT1 Polymorphisms}

The contribution of the DGAT1 K232A polymorphism to the genetic variance of unsaturation indices was lower than the contribution of the SCD1 A293V polymorphism for all indices, except for $\mathrm{C} 18$ and total index (Tables 4 and 5). When the statistical model was extended to include both the SCD1 genotype and the DGAT1 genotype as fixed effects, the effects of DGAT1 on the unsaturation indices did not change considerably, meaning that the 2 polymorphisms do not explain the same part of the genetic variation (results not shown). In other words, the genetic variation explained by DGAT1 and the genetic variation explained by SCD1 are additive. Cows with the SCD1 VV genotype and the DGAT1 AA genotype $(\mathrm{n}=41)$ have 9,6 , and $14 \%$ higher indices of $\mathrm{C} 16, \mathrm{C} 18$, and CLA, respectively, compared with cows with the SCD1 AA and DGAT1 KK genotype (results not shown, frequencies of combined genotypes in Table 6). This shows that selective breeding can improve when both the polymorphisms in SCD1 and DGAT1 are used in genetic selection.

\section{Correlations}

Phenotypic and genetic correlations were high and positive among the medium-chain fatty acid unsaturation indices $\mathrm{C} 10, \mathrm{C} 12$, and $\mathrm{C} 14$ and among the longchain fatty acid indices C18 and CLA, ranging from 0.86 through 0.98 (Table 7). Genetic correlations were low between the medium-chain and the long-chain fatty acid indices ( 0.05 to 0.26$)$. The $\mathrm{C} 16$ index showed low to moderate genetic correlations with $\mathrm{C} 10(0.15)$, $\mathrm{C} 12$ (0.37), and C14 (0.24) indices. Genetic correlations of $\mathrm{C} 16$ index with $\mathrm{C} 18$ and CLA indices were also moderate, although slightly higher $(0.45$ and 0.60$)$. Our observations are similar to the phenotypic correlations reported in previous studies (Peterson et al., 2002;

Table 6. Number of animals per combined genotype of the SCD1 A293V and DGAT1 K232A polymorphisms

\begin{tabular}{lrrrr}
\hline \multirow{2}{*}{$\begin{array}{l}\text { SCD1 A293V } \\
\text { genotype }\end{array}$} & KK & KA & AA & Total \\
\cline { 2 - 5 } & 159 & 439 & 316 & 914 \\
AA & 106 & 313 & 264 & 683 \\
AV & 16 & 59 & 41 & 116 \\
VV & 281 & 811 & 621 & $1,713^{1}$ \\
Total &
\end{tabular}

${ }^{1} 220$ animals could not be genotyped for one or both polymorphisms. 


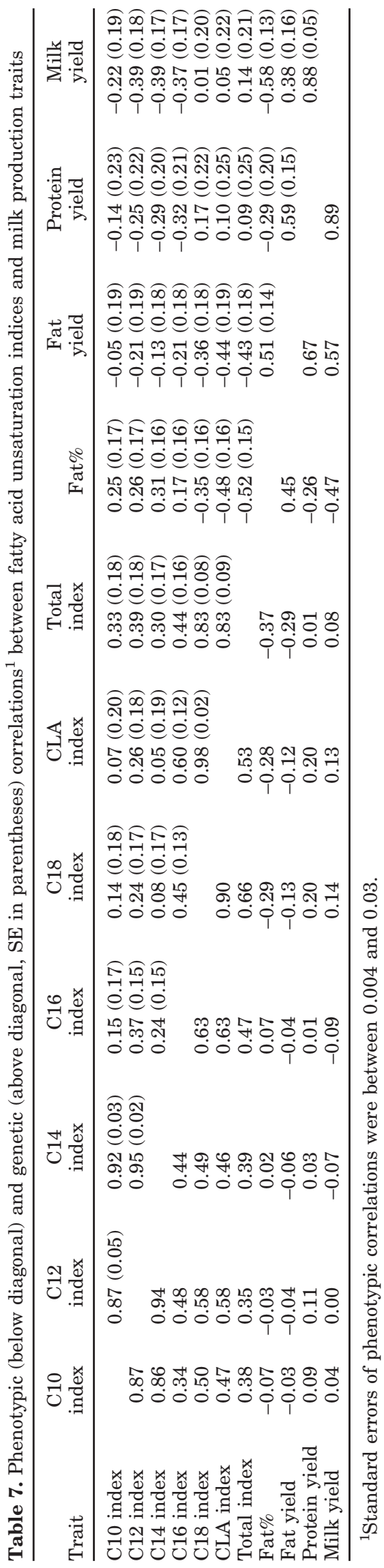

Kelsey et al., 2003). Genetic correlations of fat percentage with $\mathrm{C} 10$ (0.25), C12 (0.26), C14 (0.31), and C16 (0.17) indices were low, but positive, whereas genetic correlations of fat percentage with $\mathrm{C} 18(-0.35)$ and CLA (-0.48) indices were negative. Accordingly, an increase in fat percentage will lead to slightly higher C10, C12, C14, and C16 indices, but to lower C18 and CLA indices. Fat percentage also showed a negative genetic correlation with total index $(-0.52)$. This might partly reflect the effects of the DGAT1 K232A polymorphism, for which the $\mathrm{K}$ allele is known to have a very large effect on fat percentage. In this study, it has been shown that the $\mathrm{K}$ allele is also associated with higher C10, C12, C14, and C16 indices, and lower C18 and CLA indices. It is likely that breeding in the Dutch dairy in the past years has resulted not only in increased fat percentage and fat yield, but also in higher C10 to C16 indices and lower C18 and CLA indices.

The moderate genetic correlation between $\mathrm{C} 14$ and C16 index can be partly explained by the SCD1 polymorphism (Figure 1). Three groups can be identified in this figure, which almost completely coincide with the 3 genotypes of SCD1 A293V (AA, AV, and VV). Correction for the SCD1 polymorphism, by adding the SCD1 genotype to the model as a fixed effect, results in a higher genetic correlation between $\mathrm{C} 14$ and $\mathrm{C} 16$ index (0.93 with vs. 0.24 without correction, Table 7$)$, but also in higher correlations between $\mathrm{C} 10$ index and $\mathrm{C} 16$ index (0.69 vs. 0.15$)$ and between $\mathrm{C} 12$ index and C16 index (0.91 vs. 0.37), and between the medium chain $\mathrm{C} 10, \mathrm{C} 12$, and $\mathrm{C} 14$ indices and the long chain C18 and CLA indices ( 0.2 to 0.4 higher after correction; data not shown). Thus, the correlation due to the SCD1 A293V polymorphism is negative for these indices, whereas the correlation due to other genetic effects is positive.

\section{Impact}

We have demonstrated that milk fatty acid unsaturation indices have a substantial genetic component, indicating that it is possible to change unsaturation indices by selective breeding. Our results also show that both the SCD1 A293V and the DGAT1 K232A polymorphism explain part of the genetic variation in the unsaturation indices of milk fat. Even though the SCD1 A293V polymorphism does not affect the overall degree of unsaturation, its effects on the individual fatty acid indices offer opportunities for improving milk fatty acid composition. Human trial studies show that not all saturated fatty acids affect cholesterol concentrations to the same extent and that some are more unfavorable than others (Mensink et al., 2003). The most unfavorable, hypercholesterolemic fatty acid, is 


\section{Relation between C14 and C16 unsaturation indices}

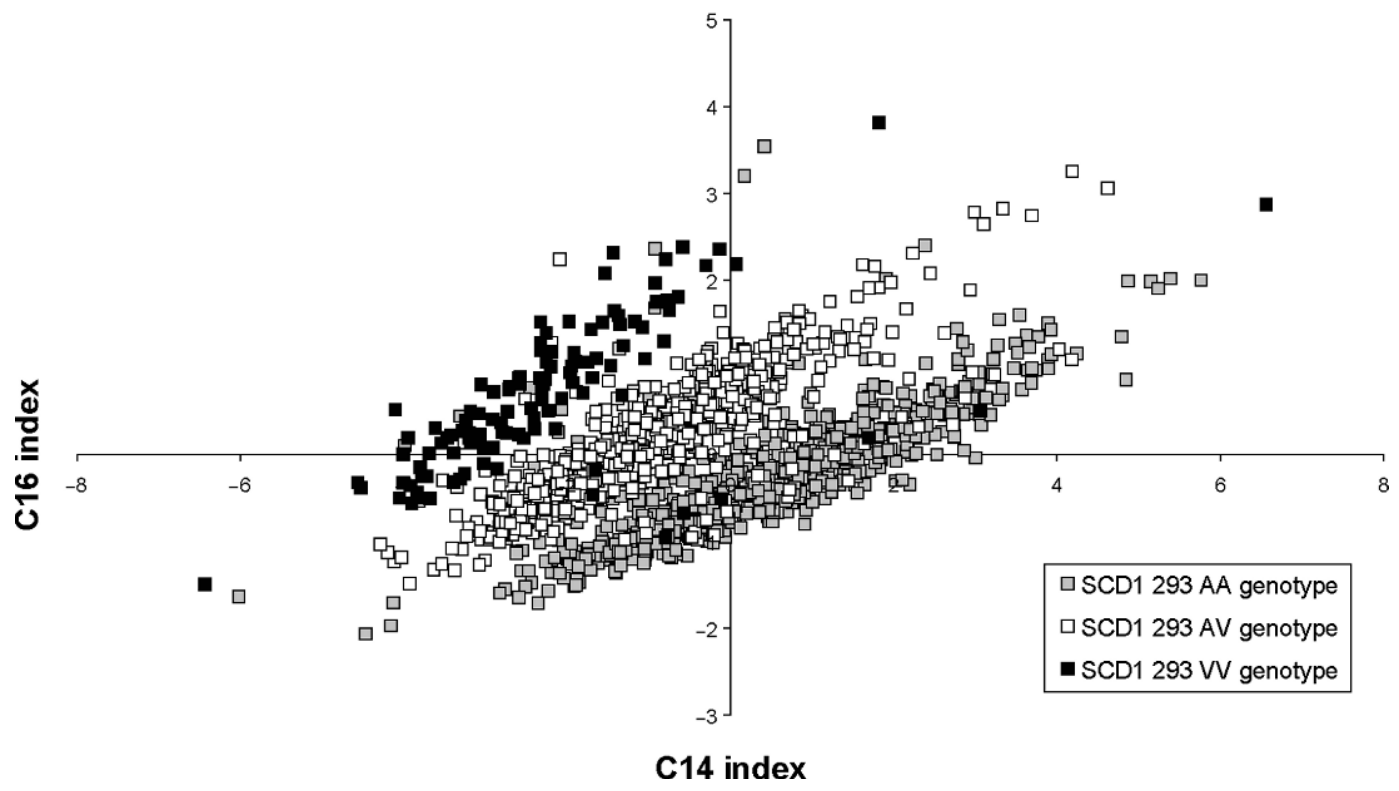

Figure 1. Relation between C14 and C16 unsaturation indices of individual cows. Phenotypes are corrected for DIM modeled with a Wilmink curve, age at first calving, calving season, differences in genetic level between groups of proven bull daughters and young bull daughters, and herd.

C16:0. Therefore, an increase of certain fatty acid indices (i.e., a shift from saturated to unsaturated) at the expense of others would be beneficial.

Our study gives more insight into the process of unsaturation. Not only does SCD1 play a significant role by desaturating saturated fatty acids into unsaturated fatty acids, but also DGAT1 is important by influencing the composition of the triacylglycerols. The entire pathway of lipogenesis, which next to SCD1 and DGAT1 involves other enzymes like fatty acid synthase and acetyl-coenzyme A carboxylase, is regulated by the transcription factor sterol regulatory elementbinding protein (SREBP)-1c and activated by dietary fatty acids. We made an important start to unravel the genetics of unsaturation, and this could be the start of other studies looking into the interaction between genetics and feeding.

\section{ACKNOWLEDGMENTS}

The authors thank the owners of the herds for their help in collecting the data. This study is part of the Milk Genomics Initiative, funded by Wageningen University, the Dutch Dairy Association (NZO), HG, and the Dutch Technology Foundation STW.

\section{REFERENCES}

Baumgard, L. H., B. A. Corl, D. A. Dwyer, A. Saebo, and D. E. Bauman. 2000. Identification of the conjugated linoleic acid iso- mer that inhibits milk fat synthesis. Am. J. Physiol. Regul. Integr. Comp. Physiol. 278:R179-R184.

Beaulieu, A. D., and D. L. Palmquist. 1995. Differential effects of high fat diets on fatty acid composition in milk of Jersey and Holstein cows. J. Dairy Sci. 78:1336-1344.

Chung, M., S. Ha, S. Jeong, J. Bok, K. Cho, M. Baik, and Y. Choi. 2000. Cloning and characterization of bovine stearoyl CoA desaturasel cDNA from adipose tissues. Biosci. Biotechnol. Biochem. 64:1526-1530.

DePeters, E. J., J. F. Medrano, and B. A. Reed. 1995. Fatty acid composition of milk fat from three breeds of dairy cattle. Can. J. Anim. Sci. 75:267-269.

Drackley, J. K., A. D. Beaulieu, and J. P. Elliott. 2001. Responses of milk fat composition to dietary fat or nonstructural carbohydrates in Holstein and Jersey cows. J. Dairy Sci. 84:1231-1237.

Enoch, H. G., A. Catala, and P. Strittmatter. 1976. Mechanism of rat liver microsomal stearyl-CoA desaturase. Studies of the substrate specificity, enzyme-substrate interactions, and the function of lipid. J. Biol. Chem. 251:5095-5103.

Gilmour, A. R., B. J. Gogel, B. R. Cullis, S. J. Welham, and R. Thompson. 2002. ASReml User Guide Release 1.0. VSN International Ltd., Hemel Hempstead, UK.

Grisart, B., W. Coppieters, F. Farnir, L. Karim, C. Ford, P. Berzi, N. Cambisano, M. Mni, S. Reid, P. Simon, R. Spelman, M. Georges, and R. Snell. 2002. Positional candidate cloning of a QTL in dairy cattle: Identification of a missense mutation in the bovine DGAT1 gene with major effect on milk yield and composition. Genome Res. 12:222-231.

Heringstad, B., D. Gianola, Y. M. Chang, J. Odegard, and G. Klemetsdal. 2006. Genetic associations between clinical mastitis and somatic cell score in early first-lactation cows. J. Dairy Sci. 89:2236-2244.

Jensen, R. G. 2002. The composition of bovine milk lipids: January 1995 to December 2000. J. Dairy Sci. 85:295-350.

Kelsey, J. A., B. A. Corl, R. J. Collier, and D. E. Bauman. 2003. The effect of breed, parity, and stage of lactation on conjugated linoleic acid (CLA) in milk fat from dairy cows. J. Dairy Sci. $86: 2588-2597$. 
Lawless, F., C. Stanton, P. L'Escop, R. Devery, P. Dillon, and J. J. Murphy. 1999. Influence of breed on bovine milk cis-9, trans11-conjugated linoleic acid content. Livest. Prod. Sci. 62:43-49.

Lengi, A. J., and B. A. Corl. 2007. Identification and characterization of a novel bovine stearoyl-CoA desaturase isoform with homology to human SCD5. Lipids 42:499-508.

Lock, A. L., and P. C. Garnsworthy. 2002. Independent effects of dietary linoleic and linolenic fatty acids on the conjugated linoleic acid content of cows' milk. Anim. Sci. 74:163-176.

Lock, A. L., and P. C. Garnsworthy. 2003. Seasonal variation in milk conjugated linoleic acid and delta9-desaturase activity in dairy cows. Livest. Prod. Sci. 79:47-59.

Mele, M., G. Conte, B. Castiglioni, S. Chessa, N. P. Macciotta, A. Serra, A. Buccioni, G. Pagnacco, and P. Secchiari. 2007. Stearoylcoenzyme A desaturase gene polymorphism and milk fatty acid composition in Italian Holsteins. J. Dairy Sci. 90:4458-4465.

Mensink, R. P., P. L. Zock, A. D. M. Kester, and M. B. Katan. 2003. Effects of dietary fatty acids and carbohydrates on the ratio of serum total to HDL cholesterol and on serum lipids and apolipoproteins: A meta-analysis of 60 controlled trials. Am. J. Clin. Nutr. 77:1146-1155.

Miyazaki, M., and J. M. Ntambi. 2003. Role of stearoyl-coenzyme A desaturase in lipid metabolism. Prostaglandins Leukot. Essent. Fatty Acids 68:113-121.

Moioli, B., G. Contarini, A. Avalli, G. Catillo, L. Orru, G. De Matteis, G. Masoero, and F. Napolitano. 2007. Short communication: Effect of stearoyl-coenzyme A desaturase polymorphism on fatty acid composition of milk. J. Dairy Sci. 90:3553-3558.

Mosley, E. E., and M. A. McGuire. 2007. Methodology for the in vivo measurement of the delta(9)-desaturation of myristic, palmitic, and stearic acids in lactating dairy cattle. Lipids 42:939-945.

Pereira, S. L., A. E. Leonard, and P. Mukerji. 2003. Recent advances in the study of fatty acid desaturases from animals and lower eukaryotes. Prostaglandins Leukot. Essent. Fatty Acids 68:97-106

Perfield, J. W., II, P. Delmonte, A. L. Lock, M. P. Yurawecz, and D. E. Bauman. 2006. Trans-10, trans-12 conjugated linoleic acid does not affect milk fat yield but reduces delta9-desaturase index in dairy cows. J. Dairy Sci. 89:2559-2566.

Perfield, J. W., II, A. L. Lock, J. M. Griinari, A. Saebo, P. Delmonte, D. A. Dwyer, and D. E. Bauman. 2007. Trans-9, cis-11 conjugated linoleic acid reduces milk fat synthesis in lactating dairy cows. J. Dairy Sci. 90:2211-2218.

Peterson, D. G., J. A. Kelsey, and D. E. Bauman. 2002. Analysis of variation in cis-9, trans-11 conjugated linoleic acid (CLA) in milk fat of dairy cows. J. Dairy Sci. 85:2164-2172.

Royal, M. D., and P. C. Garnsworthy. 2005. Estimation of genetic variation in $\Delta 9$-desaturase enzyme activity in dairy cows. Page 52 in Proc. Br. Soc. Anim. Sci., York, UK. Br. Soc. Anim. Sci., Penicuik, UK

Schennink, A., W. M. Stoop, M. H. P. W. Visker, J. M. L. Heck, H. Bovenhuis, J. J. van der Poel, H. J. F. van Valenberg, and J. A. M. van Arendonk. 2007. DGAT1 underlies large genetic variation in milk-fat composition of dairy cows. Anim. Genet. 38:467-473.

Shanklin, J., E. Whittle, and B. G. Fox. 1994. Eight histidine residues are catalytically essential in a membrane-associated iron enzyme, stearoyl-CoA desaturase, and are conserved in alkane hydroxylase and xylene monooxygenase. Biochemistry 33:12787-12794.

Sol Morales, M., D. L. Palmquist, and W. P. Weiss. 2000. Milk fat composition of Holstein and Jersey cows with control or depleted copper status and fed whole soybeans or tallow. J. Dairy Sci. 83:2112-2119.

Soyeurt, H., P. Dardenne, A. Gillon, C. Croquet, S. Vanderick, P. Mayeres, C. Bertozzi, and N. Gengler. 2006. Variation in fatty acid contents of milk and milk fat within and across breeds. J. Dairy Sci. 89:4858-4865.

Soyeurt, H., A. Gillon, S. Vanderick, P. Mayeres, C. Bertozzi, and N. Gengler. 2007. Estimation of heritability and genetic correlations for the major fatty acids in bovine milk. J. Dairy Sci. 90:4435-4442.

Stoop, W. M., J. A. M. Van Arendonk, J. M. L. Heck, H. J. F. Van Valenberg, and H. Bovenhuis. 2008. Genetic parameters for major milk fatty acids and milk production traits of Dutch Holstein Friesians. J. Dairy Sci. 91:385-394.

Taniguchi, M., T. Utsugi, K. Oyama, H. Mannen, M. Kobayashi, Y. Tanabe, A. Ogino, and S. Tsuji. 2004. Genotype of stearoyl-CoA desaturase is associated with fatty acid composition in Japanese Black cattle. Mamm. Genome 15:142-148.

Wilmink, J. B. M. 1987. Adjustment of test-day milk, fat and protein yield for age, season and stage of lactation. Livest. Prod. Sci. $16: 335-348$. 